\title{
Translanguaging strategies in describing the bi(multi)lingual profile of the novel Moarte in ținutul secuilor by Caius Dobrescu
}

\author{
Erika-Mária Tódor ${ }^{\star}$ \\ Faculty of Economics, Socio-Human Sciences and Engineering, Sapientia University, Piața Libertății 1, \\ 530104 Miercurea Ciuc, Romania
}

\begin{abstract}
Article info
History:

Received June 18, 2019

Accepted July 16, 2019

Published November 7, 2019

Key words:

translingual discourse transcultural communication bi(multi)lingual profile artistic process
\end{abstract}

\begin{abstract}
The present paper focuses on two concepts of neighbouring disciplines within literary studies (translanguaging and character profiling), following how a linguistic approach emerges in the context of literature.

Translanguaging communication situations are typical for a bi- or multilingual linguistic behaviour and they result from a holistic approach to the speaker's linguistic repertoire. The concept refers to the speaker's complex and dynamic way of expression, which activates the linguistic resources most appropriate for the given context, exceeding the limits of the spoken languages. Analysing the ways of meaning creation in the case of the said novel, the paper will attempt to see how a certain linguistic phenomenon is activated by the art of the word as a means of character profiling and creating local colour. The heuristic approach of the investigation, once the key concepts have been explained, will trace the main forms of the creation of the translanguaging space, based on the analysis of the works written after the novel in question.
\end{abstract}

\section{The space of translanguaging and literary communication}

The term translanguaging is relatively new in the field of applied linguistics and it denotes the bi- or multilingual speakers' ability to use the entire linguistic repertoire that they possess at a certain time in expressing themselves and what they intend to communicate, even if they exceed the boundaries of individual linguistic systems. The term was initially used in language teaching by Cen Williams in 1994 under the Welsh name trawsieithu (Lewis et al., in Tódor et al., 2019, p. 285) to denote the situations when children used two languages in their dialogues in school; in the cited case, the children read in Welsh and wrote or discussed the texts in English.

The concept denoted by this term refers to a social- and psycho-linguistic reality that has long been a concern of experts in the field. From a linguistic point of view, the switch between registers of communication has gained various interpretations in the course of time, which can be traced also in the different meanings that the term has acquired in different periods. The first theory of this reality is connected to the name of Ferguson (1959), who used the term diglossia to refer to the changes between the high-variety (mostly official, written) and low-variety (daily use, mainly spoken) registers of speech. This concept is reinterpreted in the writings of Fishman $(1970,2000)$, who extended the semantic scope of the term to encompass bilingual communication situations, where the different languages are activated depending on the formal (official) or informal character of the communication. A later term used in the literature was code-switching, which means the alternating use of the languages (Holmes \& Wilson, 2017), and this combinative use may be present at various levels of the linguistic system (from the phonetic-phonological to the syntactic and semantic), at the level of words, sentences and discourse. Starting from the specific context of communication, the term of code-switching is understood as depending on the motivation of the speaker, and thus the switching of the linguistic code is related to the intention of the communication

\footnotetext{
`Email address: todor.erika.m@gmail.com.
} 
(Bartha, 1999; Navracsics, 2000; Benő, 2008), such as: customization of the message, changing the subject of discussion, quotation, marking one's keeping distance, identification or non-identification with a given situation, etc. (Tódor et al., 2019, p. 209).

The holistic approach to language use has resulted in the creation of a new term that has spread relatively fast as a generic term (Wei, 2005, 2018; Cenoz \& Gorter, 2017), as an approach to language use from the perspective of the practice of speech in relation to linguistic decisions, strategies of language activation, and learning and communication experiences, as a "pragmatic theory" of language (Wei, 2018). As a result, after García \& Wei (2014, p. 45), there follows a process of meaning creation, activating all the linguistic registers that an individual possesses, as the "(...) bilingual speakers' language choice and codeswitching were network specific socio-cultural practices" (Wei, 2011, p. 2). The translanguaging approach explains the process of meaning creation in correlation with the socio-cultural and linguistic determiners of communication, as the "(t)ranslanguaging space is an intense social experience and emotional investment." (Wei, 2011, 2018).

The interpretation of the term translanguaging will continue to pose several problems, but at this time one can conclude, on the basis of research in the field, that the major difference between the two terms is the different approach to the linguistic repertoire, the ways of preservation, the quality of language acquisition, and the ways linguistic stimuli are reactivated. The Dictionary of Applied Linguistics emphasizes that "Scholars using and working with the term [translanguaging] argue that [translanguaging] is different from codeswitching because the latter concept entails the alternation of two languages as separate codes while [translanguaging] is centred not on languages but on the practices of bilinguals and assumes that multilinguals have only one complex linguistic repertoire from which they select what is needed or appropriate (Gorter \& Cenoz, 2015), thus these practices cannot be easily assigned to one language or another" (García \& Wei, 2014, p. 22)" (Tódor et al., 2019, p. 285). It is hard to delimit the scope of the terms of codeswitching and translanguaging, but the two concepts clearly belong to different theoretical approaches of being within and in-between languages, and the degree of differentiation is determined by external (such as the theoretical framework, ideology, the status of a language, etc.) and internal factors (such as: the linguistic medium familiar for the individual).

The present paper applies the term translanguaging as it offers the chance of interpreting verbal behaviour in its bipolarity. I interpret the characters' ways of manifestation on the one hand as an exhibition of their selves, the different ways of being within and between different languages, and on the other hand as responses to their socio-linguistic and interpersonal context, as natural reactions of the characters to their specific linguistic space. Melinda's portrait from the analysed novel is a representative element in this respect because of her concern and ambition to make herself understood. Caius Dobrescu's world offers scenes of spontaneous, everyday speech, where the emphasis falls on practice, on the idea of being understood. From this perspective it is interesting how the characters try to find the most appropriate words, and how they find the communication strategies to solve situations of communicational deadlock. In order to argue for bipolarity, I will use Eugen Coșeriu’s formulation from the perspective of double determination: "Language is the understanding of being, but not that of an absolute subject, or an empirical individual, but that of the historical man who, for this very reason, is at the same time a historical entity. In this sense, language is fundamental for the definition of man. On the one hand, it is logos, the understanding of the being; on the other hand, it is intersubjective logos, a form and expression of man's historicity. Man lives in a linguistic world that he creates himself as a historical being”" (Coșeriu, 2009, p. 52). Translanguaging is at the same time response activated by the socio-linguistic context, an illustration of the fact that language is a socially determined phenomenon. The writings of Gumperz (1982), Gafaranga \& Torras i Calvo (2001), Canagarajah (2011), Cenoz \& Gorter (2017) articulate the idea that this type of linguistic

\footnotetext{
a "Limbajul este înțelegere a finței, dar nu din partea unui subiect absolut, nici a individului empiric, ci din partea omului istoric care, tocmai de aceea, este în acelaşi timp o entitate socială. În acest sens, limbajul este fundamental pentru definirea omului. Pe de o parte este logos, înțelegerea ființei; pe de altă parte este logos intersubiectiv, formă și expresie a istoricității omului. Omul trăiește într-o lume a lingvistică pe care o creează el însuși ca ființă istorică” (Coșeriu, 2009, p. 52).
} 
decision fulfils an organizational role, the structuring of the discourse, as a strategy of monitoring verbal resources. Translanguaging situations refer to pragmatically motivated communication contexts (Wei, 2005, p. 2011) materialized by inserting, adopting elements of another language in spontaneous speech mainly because of more efficient communication, the precise transmission of the message, easily activated languages, or the hesitations in establishing the basic language of communication (Gafaranga \& Torras i Calvo, 2001).

The above-mentioned approaches entail different, complementary theoretical perspectives on the concept, leading to functional reinterpretations of verbal behaviour. This manner of perceiving the speaker also implies the interpretation of verbal manifestations as "iceberg" texts which are activated by the motivations and decisions of the speaker. The speaker can only be understood in a relating, participating, active way, responding to external stimuli.

Literary communication is different from everyday communication in that the former has complex interpretative values. The major difference is precisely the complementary rules of the system of literary creation (Corti, 1981, p. 82). The author of a literary work may produce individual deviations, transformations, ruptures, which outline a culturally specific semiological system. In literary communication, the relationship of the primary code or the surface meaning and the hidden meanings has a different configuration in favour of underlying meanings (Corti, 1981). Cornea (1998) remarks that literary codes actually contain an indefinite number of symbols, and they only become partially explicit. The literary text is living matter in whose fabric the artist moves by an individual law, offering one of the possible directions where virtual language can become actual. (Corti, 1981). The artistic creation activates the virtuality of language, which then outlines the secondary meaning of the text.

In the analysis of Caius Dobrescu's text, the problem of translanguaging appears precisely at the level of secondary meaning, as in this case the idiolectal code of the book is a means of characterisation of the protagonists and creation of the local colour. The reader used to the traditional means of characterisation and creation of local colour (archaisms, regionalisms or sociolect) will definitely be surprised by the configuration of the linguistic space found in the novel Death in Szeklerland. In the book, the languages and their complementarity become authentic forms of articulation of multiculturality and the re-creation of transculturality, representing strategies of organisation for the text's spatial and temporal coordinates.

\section{A few words on the book and its author}

Caius Dobrescu (born in 1966) is a contemporary Romanian poet, essayist and novelist. He debuted in 1991 as the co-author of a volume titled Pauză de respirație [Breathing pause], together with Andrei Bodiu, Marius Oprea, Simona Popescu.

The novel Moarte in tinutul secuilor [Death in Szeklerland] was published in 2017 by Crime Scene Press, as the first in the Vlad Lupu series (the two later novels are: Prafin ochi [Dust in the eyes], 2017, and Recviem pentru nimeni [Requiem for nobody], 2018). As formulated in the Argument, which presents the protagonists of the novel, the book focuses on a central event (the excavation of some old skeletons led by the main character, the archaeologist Vlad Lupu), and the connected narrations and stories created based on the main subject. In addition to this narrative design, the book also presents the psychology of rupture and the attempts to reconstruct harmony, as the protagonists socialized in the "multilaterally developed" society of the pre-1989 Revolution period with its well-elaborated means of self-defence (reading, black humour), and in the "heart of the present" they reinterpret their own existence without being able to cast off the masks of the past. The action takes place in the city of Brasov and the Szeklerland. The reading places us into an intermediary world, a world suspended between the memory of the past and the meanings of the present, between black comedy and the absurd game of masks. This world is described via a language constructed through the parallel and complementary articulation of languages. 


\section{Textual linguistics and the frameworks of the context}

The present analysis proposes an approach centred on textual linguistics, a reading that goes beyond sentence analysis, concerned with the description of the functional mechanisms of signs in the transphrastic organisation of language (Vlad, 2000), the contextual and co-textual meaning production (Coșeriu, 2013; Dospinescu, 2008), the way how the text integrates the said and the unsaid, the "word" and the "nonwords" (Nichita Stănescu), the explicit and the implicit, the iceberg text (Vlad, 2000). The language in this text becomes a strategy of organizing the framework, permitting the creation of a specific world of the discourse, of a system of meanings that is created by the mingling or fusion of the worlds of discourses articulated through differing languages. From this mingling and rupture of words and non-words ${ }^{1}$, the author reaches the level of metasemantics, a "game of language" obtained by a hyper-sign created on a level beyond sentences, cultures and languages. The author re-stages real life communication, the uses and habits of the activation of languages, for which reason he goes beyond the traditional standard norms of a linguistic system, using the artistic functions resulting from merging and intersecting different linguistic experiences. One witnesses in this text the breach of conventions, and the outline of a byper-sign ${ }^{2}$, constructed on a specific idiolectic code through translinguistic units. The author transforms thus the referential function of the language, giving it other values of expression, investing it with the functions of cultural and intercultural communication to draw portraits, places, frames, or the different faces of bi(multi)lingual behaviour. The expressivity in this context results from the vitality of translinguistic mergers. Translinguistic units appear as markers of a spatial and temporal reality and expressions of cultural interplay.

The architecture of the text encompasses the work's surface structure, presenting events, encounters, searches and discoveries. The content gains value through the form of expression. The subject level of the novel is completed by the expression level, the deep structure of the book. This is where the main questions of an interpretive reading arise from: What are the main techniques, methods and procedures which construct the deep structure of the novel? What are the main levels in painting a bilingual and bicultural portrait? In tackling these problems, I have relied on the 120 translanguaging situations I "extracted" from the text (there are many more) in order to put together the corpus of the analysis. These translanguaging units represent situations of communication that the author chooses in order to create portraits socialized in different, complementary languages and cultures.

\section{The portrait of verbal behaviour}

Another structuring element of my reading was the term portrait, used in this novel with the possibility of offering a "parallel" reading, meaning that the destinies presented describe certain intrinsic portraits, articulated in an original verbal manner. The mastery of this intrinsic perspective is best perceived when the self placed in different situations of action and communication defines itself by the experiences of the past and the presence, the narrations of the self becoming thus intertextual (in which case I dare say that, short of previous readings, the reader may not reach a deeper reading).

The creation of the portraits follows the fundamental levels presented in the synthetic table below. One can distinguish three levels: A) the intercultural textuallevel (the term culture referring here to culture gained by reading), B) the inter-discourse level at the meeting point of old and updated texts and reading

\footnotetext{
${ }^{1}$ I am using the two well-known terms of Stănescu's poetry adapted to the context. In this context, I use the term word as an autonomous lexical unit which, in a linguistic system, can be perceived as a bipolar meeting between the signifier and the signified. The term non-word I use to refer to the lexical units that are only referential from the perspective of another linguistic system.

${ }^{2}$ I use the term hyper-sign meaning a text constructed by the transformation or imitation of another text (Nagy, 2015; Corti, 1981).
} 
experiences, and C) the translanguaging level, the situations of communication characterised by various forms of linguistic interplay.

\section{Levels of reading Referent Examples from the novel}

\begin{tabular}{|c|c|c|c|}
\hline & $\begin{array}{l}\text { Intercultural } \\
\text { textual level }\end{array}$ & $\begin{array}{l}\text { The culture of } \\
\text { reading }\end{array}$ & $\begin{array}{l}\text { Eng: “The Monty Python of Brasov" (9p), “... it's } \\
\text { clear, like every Little Red Riding Hood, you are } \\
\text { attracted by the wolf first" }(18 \mathrm{p}) \\
\text { Ro: "Monty Pyton-ul brașovean" ( } 9 \mathrm{p}) \text {, "...e clar, } \\
\text { ca pe orice Scufță Roșie, te atrage în primul rând } \\
\text { lupu" (18p) }\end{array}$ \\
\hline 2. & $\begin{array}{l}\text { Inter-discourse } \\
\text { level }\end{array}$ & $\begin{array}{l}\text { A sentence that } \\
\text { has other } \\
\text { sentences attached } \\
\text { to it }\end{array}$ & $\begin{array}{l}\text { Eng: "So, from Arad, horonka-tronka” ( } 27 \mathrm{p}) \\
\text { Ro: „Assa, de la Arad, horonka-tronka” ( } 27 \mathrm{p}) \\
\text { Eng: "he just throws something at you that it scares } \\
\text { the shit out of you” ( } 89 \mathrm{p}) \\
\text { Ro: "trântește o de-asta de-a lui, de stă mâța-n } \\
\text { coadă." ( } 89 \mathrm{p})\end{array}$ \\
\hline & $\begin{array}{l}\text { Translanguaging } \\
\text { level }\end{array}$ & & $\begin{array}{l}\text { Eng: “Afon, yes, áfonya, as Melinda would say. You } \\
\text { know what áfonya is? Blueberry!" (15p) } \\
\text { Ro: “Afon, da, áfonya, cum ar spune Melinda. Știi } \\
\text { ce înseamnă afonya? Afine!” (15p) }\end{array}$ \\
\hline
\end{tabular}

Table 1: Levels of the creation of a bilingual, bicultural portrait

The novel's style illustrates a natural, playful intertextuality. Some illustrative examples: "The Monty Python from Brasov" (p. 9), "it's clear, like every Little Red Riding Hood, you're attracted by the wolf in the first place" (p. 18.), "... If you tell me to bring up everything I remember faster, like on a shrink's sofa..." (p. 9), "But me, my dear, I'm gonna talk to you in the direct and clear style of post-68 Germany. In which Luther's frankness crossed with Janis Joplin's visceral moaning and Rotte Armee Faktion's sexual Marxism" (p. 16), "Where you don't know who lives, as that filthy clown used to sing in the Fat Man's club..." (p. 10), "But the Maffia are people too. In fact, everywhere's the same, Ohm's law: be a man with me, so that I be a man with you"b (p. 20).

The second level is the inter-discourse level, meaning a sentence that has its margins populated by other sentences (Foucault's terminology, in Dospinescu, 2008), an alternative to intertextuality, the interaction "of two or more discourses whose original configuration cannot be reconstructed, but favours the production of implicit meanings"... (Nagy, 2015, p. 194). The inter-discourse prepares the elements of the intra-discourse as a topos of the rules which follow the logic of the basic language, without the support of other elements to produce understanding (Nagy, 2015). The intra-linguistic level of the text brings in this case translingual elements and situations of communication, based on the breach in the coherence of a linguistic system by the complementary activation of languages. Some illustrative examples from the novel:

"...searching through key rings with flashlights, nail clippers, 3D icons, screaming monkeys whose eyes light up red when you push their ears, piles of post-its, and especially, yes, especially, über alles, überhaupt, ball pens. Tens and tens of them." (7)

„Ok. You're interested in Vlad. Yes, you are. Stop bullshiting me [sic!], don't give me crap about the dynamics of mentalities, social networks or counter-culture in Ceausescu's time." (9)

The novel starts off with the voice of the narrative self, on his way to the place of the action. The introduction to the place and atmosphere of the plot happens by the introduction of a multilingual space:

\footnotetext{
${ }^{\mathrm{b}}$ A play on words in Romanian, based on the identical pronunciation of the name Ohm and the noun 'om', meaning a man, a person [translator's note].
} 
the dominant, basic language of the communication is Romanian, but depending on the situation, other languages are also used: German, Hungarian, English. The suffocating atmosphere in the train represents the protagonist's perception of the Balkan chaos looking at this world from an outsider's perspective, but gradually, as he arrives to the Szeklerland, becoming the actor of the relational field. The atmosphere in the train is described suggestively: "Listen to me carefully, schau mal, you're half asleep, three quarters asleep, quatsch, I don't know how much..." (7); "... and so here we are again in Romania. Well, actually in Szeklerland, Szekelyfold, Țara Secuilor. (18).

The third textual level is, by its linguistic organisation, the translingual level which acquires different shapes and refers to different units or levels of the language. The text contains:

a. Translanguaging situations with high interferential level in the text:

"Igen, nemzetkozi, international. He was at the Olympics, and so ... world champion at... hey, how do say that? ... asztalitenisz" (24)

"He ran somewhere" (27)

b. Translanguaging situations with adapted foreign word:

"It seems that one of your Rumäniendeutscher, a German from Romania is also involved in this whole business" (19)

"to throw a buliparty" (29)

"but for the time being all this stuff in my head seemed to get in stand-by" (44)

c. Translanguaging situations through inserted words and structures:

"Afon, yes, áfonya, as Melinda would say. You know what áfonya is? Blueberry!" (15)

"it was echt, it was real" (14)

"So. Yeah, it's him... And he's puszipajtás, they're great pals with Marin Manta" (29)

"What pastor Astner teaches us in catechism is not just a Witz, a joke" (40)

"Well, I say predestination when I look back. Because, ach, du, Karina, süßes Kind, wasn't the bole in the middle of the house a sign, a prefiguration?" (41)

d. Situations of using elements of oral communication of a different language:

"Well, in a way, that steamy being, the salesman-nymph, naiada-pusher, took me to her. Which means it is OK, this is how it was meant to be. Musai. A szerelemnek, I think they call it. A szerelem. La Melinda." (8)

"In care nu știi ci-i-neşa-a-ade...” (41)

"Of course he hastened at me:

- Ioi, auch, sorry, sorry, bocs!" (48)

In the case of these linguistic passages or transpositions, the author is also mindful of his audience, of how the understanding happens, even with a monolingual speaker or a speaker for whom not knowing certain words in the other language might be a hindrance in understanding. The solution found for these situations is the repetition or reformulation of the message in the basic language of communication. Some examples from the novel: "Eintritt streng verboten. Entry strictly forbidden. No one else was allowed in there except for the staff" (42); "Fresse des Mörders. The murderer's face" (13).

In shaping the portraits, beyond the "to-and-fro" between two or three languages, there are also scenes which indirectly display other elements of verbal behaviour as well. There are illustrative situations of communication which betray how the speakers compensate for their lack of vocabulary or uncertainty in expression through various strategies of looking for the right word, such as: explanatory descriptions to 
make themselves understood, or using their entire linguistic repertoire, regardless of individual linguistic systems:

V. Lupu in his discussion with Melinda:

"- There's big problem with the son, you know, the son...

- Whose son?

- Of thisman.

- I had no idea about Manta's son. Although it turned out I should have had." (26)

"That's also because he's not, you know, in the country. It seems he ran somewhere in the Karibik [Caribbean], you know, some trópusi sziget, you know.

- A tropical island? I raised my eyebrows even higher.

- Igaz, that's right, tropical, and he gives sometimes like you know, at the revolution, what's it called, you know, proclamation..." (27)

"It doesn't get into his head how important this is, az erdo", the forest, the lungs with which the bolygó, the planet breaths..." (28)

With the spontaneous speech of the characters, the narrator's voice is also heard once in a while, reflecting on the characters' way of speech: "Ach, how sweet was the mixture of the Szekler accent and the Transylvanian accent of the Vlachs, the Bloch-s, as my Saxon ancestors would have said..." (28)

\section{Another kind of portrait... in the mirror}

The pleasure of reading this novel is primarily due to the ruptures and fusions of alterity, the redistribution of language. What we see here is a kind of "making holes in the discourse without turning it meaningless" (Barthes, 1994, p. 15), because the linguistic ruptures in the text are supervised precisely in order to render the spontaneous manifestations of bi(multi)lingual and bi(multi)cultural speakers. This is the sociolinguistic print of verbal behaviour, achieved by the stylistic refinement of the syntagmatic structure. A similar portrait of the same socio-cultural and linguistic topos appears also in a different novel, published in the same year as Caius Dobrescu's work: the indirect characterisation of bilingual behaviour in Gábor Vida's Egy dadogás története [The story of a stutter]. This book displays an inverted portrait of bilingual verbal behaviour, as far as it is about the substitution, or even repression, rather than exploitation, of linguistic repertoires, in the portrait of uncle Fjodor (nea, nenea Fjodor), a Hungarian turned Romanian.

“... Nea Fjodor considered himself Hungarian, but spoke Romanian better, he spoke a strange mixture of a language, which later reminded me of the Csángós, although his Hungarian intonation was like in the plains, his Romanian accent wasn't local, but similar to how people of Oltenia spoke, Romanian musicality and Hungarian roughness were in a strange opposition in his speech. He would always apologize to us for not speaking good Hungarian. This was annoying me, for I had the feeling he spoke very good Hungarian, only he didn't really want to speak it."

(Vida, 2017, p. 185)

This portrait offers another inherent dimension of verbal behaviour, which, contrary to the free, heterogeneous and complementary activation of languages in the case of Caius Dobrescu's characters, displays the image of linguistic vitality closed within restrictive, controlling frameworks.

\section{Conclusions}

Focusing on the world created by Caius Dobrescu in his novel Death in Szeklerland, this paper tried to grasp the ways that language becomes an element of the architecture of creation in the text. This way of reading should of course be followed by a similar examination of the ensuing novels in this cycle, to see 
Erika-Mária Tódor

whether the procedures listed here are taken over and used in the other novels as well. Clearly, in this novel the inter-linguistic ruptures and the fusion of alterities result in the redistribution of language. The author creates a hyper-sign constructed on a specific idiolectal code, translingual and transphrastic, offering the possibility of a metasemantic interpretation. The expressiveness comes from making use of the vitality of translingual fusions.

Through these passages, these to-and-fro movements between languages, the referential function of languages receives other values, incorporating through its primary and secondary meanings different cultural and intercultural functions. The novel presents portraits, places, spaces, frames and faces in this context, which all together represent something of the effort to search the right word through relating it to the multilingual landscape and behaviour specific to a given socio-cultural space.

\section{Bibliography}

Auer, P. (ed.) (1998). Code-switching in Conversation: Language, Interaction and Identity, Routledge, London.

Bartha, Cs. (1999). A kétnyelvüség alapkérdései [Introduction to Bilingualism], Nemzeti Tankönyvkiadó, Budapest.

Barthes, R. (1994). Plăcerea textului [The Pleasure of the Text], Echinox, Cluj Napoca

Benö, A. (2008). Kontaktológia. A nyelvi kapcsolatok alapfogalmai [Linguistic Contactology. Basic Concepts of Language Contact], Egyetemi Mühely, Kolozsvár.

Canagarajah, S. (2011). Codemeshing in academic writing: Identifying teachable strategies of translanguaging, in "The Modern Language Journal", 95 (3), p. 401-417, Crossref.

Cenoz, J. \& Gorter, D. (2017). Translanguaging as a pedagogical tool in multilingual education, in Cenoz, J., Gorter, D. \& May, S. (eds), Language awareness and multilingualism, Springer International Publishing, Dordrecht, p. 309-321, Crossref.

Cornea, P. (1998). Introducere in teoria lecturii [Introduction to the Theory of Reading], Polirom, Iași.

Corti, M. (1981). Principiile comunicării literare [Principles of Literary Communication], Editura Univers, București.

Coșeriu, E. (2009). Omul și limbajul său [The Man and His Language], Editura Universităţii “Alexandru Ioan Cuza”, Iași.

Coșeriu, E. (2013). Lingvistica textului. O introducere in hermeneutica sensului [Linguistic of Text. An Introduction to the Hermeneutics of Meaning], Editura Universității “Alexandru Ioan Cuza”, Iași.

Dobrescu, C. (2017). Moarte in ținutul secuilor [Death in Szeklerland], Crime Scene Press, București.

Dospinescu, V. (2008). Eugen Coșeriu și lingvistica textului [Coșeriu Eugen and Linguistic of Text], in "Limba română”, 17 $(5-6)$.

Ferguson, Ch. (1959). Diglossia, in Bratt Paulston, C. \& Tucker, R. G. (eds), Sociolinguistics. The essential readings, Blackwell Publishing, Malden (MA), p. 345-358.

Fishman, J. (1970). Sociolinguistics: a brief introduction, Newbury House, Rowley (MA).

Fishman, J. (2000). Bilingualism with and without diglossia; diglossia with and without bilingualism, in Wei, L. (ed.), The bilingualism reader. Routledge, London - New York, p. 81-88.

Gafaranga, J. \& Torras i Calvo, M.-C. (2001). Language versus medium in the study of bilingual conversation, in "International Journal of Bilingualism", 5 (2), p. 195-219, Crossref.

García, O. \& Wei, L. (2014). Translanguaging: language, bilingualism and education, Palgrave Macmillan, New York, Crossref.

Gorter, D. \& Cenoz, J. (2015). Translanguaging and linguistic landscapes, in "Linguistic Landscape", 1 (1), p. 54-74, Crossref.

Gumperz, J.J. (1982). Discourse strategies, Cambridge University Press, Cambridge, Crossref.

Holmes, J. \& Wilson, N. (2017). An Introduction in Sociolingvistics ( $5^{\text {th }}$ edition), Routledge, London - New York.

Nagy, R. (2015). Dicționar de analiză a discursului [Dictionary of Discourse Analysis], Institutul European, Iași.

Navracsics, J. (2000). A kétnyelvü gyermek [The Bilingual Child], Corvina, Budapesta.

Tódor, E.-M. (coord.), Bartha, K., Benő, A., Dégi, Zs., Magyari, S. \& Tankó, E. (2019). Alkalmazott nyelvészeti szótár (A két- és többnyelvüség alapfogalmai) [Dictionary of applied linguistics (Basic concepts of bi- and multilingualism)], Presa Universitară Clujeană, Cluj-Napoca.

Vida, G. (2017). Egy dadogás története [The story of a stutter], Magvető, Budapesta.

Vlad, C. (2000). Textul aisberg. Elemente de teorie şi analiză [The iceberg text. Elements of theory and analysis], Casa Cărții de Ştiință, Cluj-Napoca.

Wei, Li (2005). 'How can I tell?'. Towards a common sense explanation of conversational code-switching, în “Journal of Pragmatics”, 37 (3), p. 375-389, Crossref.

Wei, Li (2011). Moment analysis and translanguaging space. Discursive construction of identities by multilingual Chinese youth in Britain, in "Journal of Pragmatics", 42 (5), p. 1222-1235, Crossref.

Wei, L. (2018). Translanguaging as a Practical Theory of Language, in "Applied Linguistics”, 39 (1), p. 9-30, Crossref. 